\title{
Physico-Chemical Soil Properties and Their Correlations with Maize and Cassava Production in Ebonyi, Nigeria
}

\author{
Fidelis Chinazor Okorie ${ }^{*}{ }^{\circledR}$, John Didacus Njoku², Emmanuel Uzoma Onweremadu ${ }^{3}$, \\ Martin Chidinma Iwuji ${ }^{2}$ \\ ${ }^{1}$ Department of Geography and Environmental Management, Imo State University, Owerri, Nigeria \\ ${ }^{2}$ Department of Environmental Technology, Federal University of Technology, Owerri, Nigeria \\ ${ }^{3}$ Department of Soil Science, Federal University of Technology, Owerri, Nigeria \\ Email: ${ }^{\star}$ fidelisokorie@yahoo.co.uk
}

How to cite this paper: Okorie, F.C., Njoku, J.D., Onweremadu, E.U. and Iwuji, M.C. (2020) Physico-Chemical Soil Properties and Their Correlations with Maize and Cassava Production in Ebonyi, Nigeria. American Journal of Climate Change, 9, 34-51. https://doi.org/10.4236/ajcc.2020.91004

Received: September 21, 2019

Accepted: March 9, 2020

Published: March 12, 2020

Copyright $\odot 2020$ by author(s) and Scientific Research Publishing Inc. This work is licensed under the Creative Commons Attribution International License (CC BY 4.0).

http://creativecommons.org/licenses/by/4.0/

\begin{abstract}
This study analyzed relationships between soil properties and food crop production in Ebonyi State of southeast Nigeria. Free survey was conducted after three zones (Agbaja, Akaeze and Ikwo) in the state were purposely selected for representation of the soil sampling. Two types of sampling were conducted; Auger sampling at $0-20$ and $20-40 \mathrm{~cm}$ depths and soil profile sampling. Annual crop yield data on maize and cassava for the state from 1988 to 2017 were collected from Agriculture Development Program. Variations in properties among soil horizons were obtained using coefficient of variations while soil parameters were regressed against crop yields to establish their relationships. Results showed that fine sand, total sand, bulk density, total porosity, soil $\mathrm{pH}$, and available phosphorus significantly $(\mathrm{p}=0.05)$ differ from $0-20$ $\mathrm{cm}$ and $20-40 \mathrm{~cm}$ depths. Also, cassava yield correlated negatively with base saturation, and organic matter at 0.05 probability level; with exchangeable $\mathrm{Ca}$ and $\mathrm{Na}$ at 0.01 probabilities level but correlated positively with bulk density and available water capacity at 0.01 and 0.05 probability levels, respectively. Similarly, maize yield correlated negatively with available phosphorus and total nitrogen at 0.05 probability level; and with total porosity and exchangeable $\mathrm{Ca}$ at 0.01 probability level; and then correlated positively with available water capacity, and bulk density, at 0.01 probability level; with coarse sand at 0.05 probability level. However, soils of Ebonyi State are fertile but some of the chemical properties are still low, therefore, it is paramount to improve the quality of the soil to achieve improved food security in the state.
\end{abstract}

\section{Keywords}

Soil Parameters, Crop Yield, Relationships, Food Security, Ebonyi State, Nigeria 


\section{Introduction}

According to [1], there are strong indications and evidences that the agricultural and food system as well as the rural area across the world are experiencing major climatic changes. They affirmed that the changes had drastically reduced soil fertility and led to poor agricultural outputs particularly in sub-Saharan Africa. Also [2] noted that the low-available water holding capacity of the soil result to poor crop growth in the tropics. In another study, [3] submitted that temperature and precipitation have opposite effects on yield levels and variability of crops because they influence soil moisture, which in turn could affect soil fertility. Supporting the above remark, [4] observed that the major agro-climatic constraints on agricultural production are related to insufficient, excessive or irregular moisture supply, which in turn will affect the length of growing period (LGP) of crops.

The recurrent food crisis in Nigeria is partly due to the high rate of population growth over food production level and erratic amounts of food crops produced from year to year. However, this can be attributed to high susceptibility of the country to serious environmental hazards extreme climate events, poor soil quality, deforestation, continuous cropping and unhindered desert encroachment [5]. From the foregoing, it is clear that there are many factors that affect the growing period of crops, which to a greater extent determine the crop growth cycle and its yield.

Irrespectively, soil indicators present major determinant in the growth and production of food crops. Soil properties therefore, are among major physical environmental factors that can increase or decrease crop production. Plants grown on land completely depend on soil on which they grow. Obviously, soil parameters, which influence crop production, are also affected by both natural and human induced factors. Soil factors affecting crop production therefore, include soil moisture (water), soil air, soil temperature, soil mineral matter, soil organic matter, soil organisms and soil reaction, which is the $\mathrm{pH}$ (hydrogen ion concentration) of the soil. In Ebonyi State of Nigeria, there is evidence of global food security crises because food production has not over the years kept pace with growing population in the area. The decrease in food crop production in the state is therefore, attributed to low or poor quality of the soils among other factors. It is on this premise this research is based on the aim to analyze the relationships between physico-chemical soil properties and food crop production in the state.

\section{Description of the Study Area}

Ebonyi State is one of the states in Southeast Nigeria as shown in Figure 1. The state lies approximately within latitudes $5^{\circ} 40^{\prime}$ and $6^{\circ} 45^{\prime}$ north of the Equator and longitudes $7^{\circ} 30^{\prime}$ and $8^{\circ} 30^{\prime}$ east of the Greenwich meridian. The prevailing climatic condition in the area is characterized primarily by two major regimes which are the rainy and dry seasons. The rainy season usually starts in April through October; 


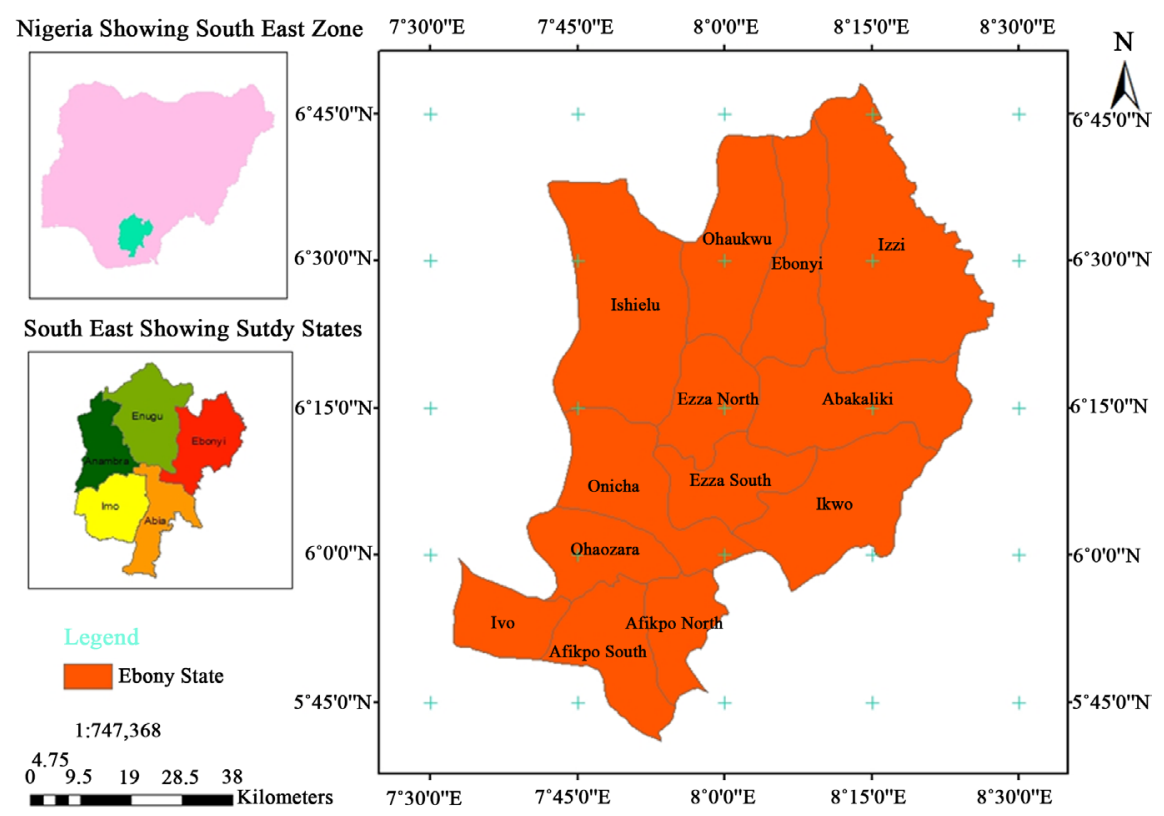

Figure 1. Directional map showing Ebonyi State, Southeastern, Nigeria.

while the dry season starts from October to February, which is the same throughout southeast Nigeria. The state experiences bimodal rainfall pattern with first peak in July and the second in September, and annual rainfall is usually between $1613.8 \mathrm{~mm}$ to $2136.27 \mathrm{~mm}$. Dry season begins in November, when the dry continental North-eastern wind blows from the Mediterranean Sea across the Sahara desert and Samarian desert and down to the southern part of Nigeria. The state is known for agriculture especially crop farming. Agriculture is a very significant sector of the economy for the state and the sources of raw materials used in the processing industries which serve as important area of employment and income generation for the people.

Based on vegetation, Ebonyi is divided into two, the Southern forested Ebonyi and the derived savanna of Ebonyi North. Yet, the vegetation as one transit from the forested south is thicker than the northern part of Ebonyi State. Consequent upon this, the state is divided into three zones for the purpose of soil sampling, namely Ebonyi South, Ebonyi Central and Ebonyi North. The state capital is Abakaliki and the state is known for its salt deposits, while other minal deposits found in the state are zinc, lead, limestone, granite, refractory clay and gypsum.

\section{Materials and Methods}

The study involved both primary and secondary data sources and acquisitions.

Free survey was employed for the study after the three zones in the state was purposely selected for representation of the soil sampling. The zones include Agbaja in Izzi LGA (Ebonyi North), Akaeze in Ezza North LGA (Ebonyi Central) and Ikwo in Ikwo LGA (Ebonyi South) (see Figure 1). The free survey was guided by size and extent of farming activities in each zone. Two types of sampling were conducted; Auger sampling was conducted at $0-20$ and $20-40 \mathrm{~cm}$ 
depths for arable crop production purposes while soil profile sampling was done for in-depth characterization and scientific classification of soils. Soil profile was dug, described and sampled using standard procedures as recommended by [6] Soil samples were collected based on horizon differentiation and sampling started from the deepest horizon upwards in each soil profile. In each location, 10 auger samples of the same depth were collected and bulked to form a composite sample for laboratory analyses.

The secondary data involved collection of annual crop yield data on maize and cassava (in kilogrammes/hectare) for Ebonyi State over 30 years ranging from 1988 to 2017. The crop yield data were obtained from Agriculture Development Programme (ADP) headquarters in Abakaliki. The crop yield data are presented in Table 1 and both edaphic data and crop yield data were analyzed statistically to determine their relationships.

Table 1. Crop yield for Ebonyi State in metric tons (1988-2017).

\begin{tabular}{|c|c|c|}
\hline Year & Maize & Cassava \\
\hline 1988 & 2.78 & 10.11 \\
\hline 1989 & 2.50 & 9.00 \\
\hline 1990 & 2.50 & 9.40 \\
\hline 1991 & 3.70 & 12.05 \\
\hline 1992 & 2.99 & 11.85 \\
\hline 1993 & 3.06 & 12.56 \\
\hline 1994 & 3.80 & 12.85 \\
\hline 1995 & 3.88 & 12.88 \\
\hline 1996 & 4.80 & 12.90 \\
\hline 1997 & 3.80 & 11.59 \\
\hline 1998 & 2.18 & 12.50 \\
\hline 1999 & 2.18 & 15.75 \\
\hline 2000 & 1.96 & 14.57 \\
\hline 2001 & 2.03 & 15.52 \\
\hline 2002 & 2.03 & 15.52 \\
\hline 2003 & 2.01 & 15.85 \\
\hline 2004 & 1.93 & 14.63 \\
\hline 2005 & 2.01 & 14.20 \\
\hline 2006 & 2.04 & 15.01 \\
\hline 2007 & 2.04 & 15.01 \\
\hline 2008 & 2.07 & 15.00 \\
\hline 2009 & 2.11 & 15.18 \\
\hline 2010 & 3.70 & 13.10 \\
\hline 2011 & 3.85 & 12.80 \\
\hline 2012 & 3.85 & 13.80 \\
\hline 2013 & 4.50 & 13.20 \\
\hline 2014 & 4.55 & 13.35 \\
\hline 2015 & 5.50 & 13.25 \\
\hline 2016 & 5.00 & 13.85 \\
\hline 2017 & 4.85 & 13.75 \\
\hline TOTAL & 94.20 & 401.03 \\
\hline
\end{tabular}

Source: ADP, Abakaliki, Ebonyi State, Nigeria. 


\subsection{Laboratory Studies}

Soil samples were air-dried and sieved using 2-mm sieve and the particle size distribution was determined by hydrometer method [7] while bulk density was measured by core procedure [8]. Results from particle size analysis (sand, silt and clay) values were used to obtained textural class using textural triangle. Bulk density values were used to calculate total porosity of soils given a relationship between bulk density and particle density [9].

$$
\text { Total Porosity }(\mathrm{TP})=\frac{\mathrm{BD}}{\mathrm{PD}} \times \frac{100}{1}
$$

where $\mathrm{BD}=$ determined bulk density, $\mathrm{PD}=$ particle density assured to be 2.65 $\mathrm{mg} \cdot \mathrm{m}^{-3}\left(2.65 \mathrm{~g} / \mathrm{cm}^{-3}\right)$.

Gravitaional moisture content $(\theta \mathrm{m})$ was measured using the procedure as outlined in Obi (1990).

$$
\theta \mathrm{m}=\frac{\mathrm{WS}-\mathrm{DS}}{\mathrm{DS}} \times \frac{100 \%}{1}
$$

where $\theta \mathrm{m}=$ gravitmetric moisture content; WS = weight of wet soil sample; DS $=$ weight of dry soil sample; AWC $=\mathrm{FC}-\mathrm{PWP}$.

Soil $\mathrm{pH}$ water and $\mathrm{pH}$ KCL were determined electronically in 1:2.5 soil solutions ratio according to [10].

Soil organic Carbon was measured by wet digestion using the procedure outlined in [11] while soil organic matter was calculated by multiplying organic carbon value by 1.724. Exchangeable basic cations were extracted using ammonium acetate at $\mathrm{pH}_{7}$ and therefore, exchangeable calcium and magnesium were determined using ethylene diamine-tetraascetic acid (EDTA) titration, and exchangeable potassium and sodium were determined by flame photometry (Soil Survey Staff, [11]. Exchangeable acidity (exchangeable hydrogen and aluminum) were measured by apparent titration [12]. Cation exchange capacity (ACEC) was measured at $\mathrm{pH}$ of 7.0 (neutral) [11].

Total nitrogen (TN) was determined by micro-kjedahl apparatus [13]. Available phosphorous was estimated by Bray 2 method according to procedure of [14]. Base saturation was computed as a sum of exchangeable basic cations (Ca, $\mathrm{Mg}, \mathrm{K}, \mathrm{Na}$ ) divided by Cation Exchange Capacity, multiplied by 100\% [11].

\subsection{Date Analytical Techniques}

Soil data from auger samples were subjected to analysis of variance (ANOVA). Therefore, variation in properties among soil horizons were obtained using coefficient of variation. Also, the correlation coefficient ( $r$ ) and the coefficient of determination for simple linear regression $\left(\mathrm{r}^{2}\right)$ were calculated to determine the degree of association or relationship among some physico-chemical properties of the soils from selected profiles around the study area. Similarly, edaphic (soil) parameters (independent variables) were regressed against crop yield (dependent variables) to establish relationship existing among some soil properties and the crops. 


\section{Results}

\subsection{Crop Yield for Ebonyi State}

The yields for the arable crops in metric tons for the entire state are presented in Table 1. Results show that maize yield in 1988 was $2.78 \mathrm{~m} /$ ton and cassava, 10.11 $\mathrm{m} /$ ton but in 1998 maize yield dropped to $2.18 \mathrm{~m} /$ ton and cassava increased to $12.50 \mathrm{~m} /$ ton, while in 2008 maize yield decreased further to $2.07 \mathrm{~m} /$ ton and cassava increased to $15.00 \mathrm{~m} / \mathrm{ton}$, and in the last study year (2017) maize yield increased to $4.85 \mathrm{~m} /$ ton and cassava decreased to $13.75 \mathrm{~m} /$ ton.

\subsection{Soil Physical Properties in Ebonyi State}

Soil physical properties in Ebonyi State are presented in Table 2. Results showed that at $0-20 \mathrm{~cm}$ depth, CS, FS, TS and Si ranged from $100-150,230-510,330-$ 660 , and $220-500 \mathrm{~g} / \mathrm{kg}$ respectively in the three studied location (Akaeze, Agbaja and Ikwo). The clay content ranged from $90-170 \mathrm{~g} / \mathrm{kg}$ while bulk density ranged from $1.22-1.30 \mathrm{~g} / \mathrm{cm}^{3}$. Total porosity was within the range of $50.94 \%$ $53.96 \%$ while moisture content ranged from $18.22 \%-20.03 \%$. FC, PWP and AWC ranged from $0.23-0.25,0.111-0.126$, and $0.118-0.122 \mathrm{~g} / \mathrm{kg}$ respectively.

Table 2. Physical properties of soils of Ebonyi State.

\begin{tabular}{|c|c|c|c|c|c|c|c|c|c|c|c|c|}
\hline \multirow{2}{*}{ Location } & CS & FS & TS & $\mathrm{Si}$ & $\mathrm{Cl}$ & \multirow{2}{*}{$\mathrm{TC}$} & BD & $\mathrm{TP}$ & $\emptyset \mathrm{m}$ & FC & PWP & AWC \\
\hline & $\mathrm{g} / \mathrm{kg}$ & $\mathrm{g} / \mathrm{kg}$ & $\mathrm{g} / \mathrm{kg}$ & $\mathrm{g} / \mathrm{kg}$ & $\mathrm{g} / \mathrm{kg}$ & & $\mathrm{g} / \mathrm{cm}^{3}$ & $\%$ & $\%$ & $\mathrm{~g} / \mathrm{kg}$ & $\mathrm{g} / \mathrm{kg}$ & $\mathrm{g} / \mathrm{kg}$ \\
\hline \multicolumn{13}{|c|}{ Sampling depth $(0-20 \mathrm{~cm})$} \\
\hline Akaeze & 100.0 & 510.0 & 660.0 & 220.0 & 120.0 & SL & 1.29 & 51.32 & 19.08 & 0.25 & 0.126 & 0.120 \\
\hline Agbaja & 150.0 & 250.0 & 400.0 & 510.0 & 90.0 & $\mathrm{SiL}$ & 1.30 & 50.94 & 18.22 & 0.23 & 0.111 & 0.122 \\
\hline Ikwo & 100.0 & 230.0 & 330.0 & 500.0 & 170.0 & $\mathrm{SiL}$ & 1.22 & 53.96 & 20.03 & 0.24 & 0.121 & 0.118 \\
\hline Mean & 116.7 & 330.0 & 463.3 & 410.0 & 126.7 & $\mathrm{SL}$ & 1.27 & 52.07 & 19.11 & 0.24 & 0.119 & 0.120 \\
\hline CV (\%) & 24.70 & 47.30 & 37.50 & 40.20 & 31.90 & & 3.40 & 3.20 & 4.70 & 2.70 & 6.40 & 1.70 \\
\hline SE & 28.9 & 156.2 & 173.9 & 164.6 & 40.4 & & 0.04 & 1.65 & 0.91 & 0.01 & 0.008 & 0.020 \\
\hline \multicolumn{13}{|c|}{ Sampling depth $(20-40 \mathrm{~cm})$} \\
\hline Akaeze & 230 & 400 & 630 & 230 & 140 & $\mathrm{SL}$ & 1.43 & 46.03 & 19.36 & 0.311 & 0.123 & 0.188 \\
\hline Agbaja & 75 & 300 & 375 & 515 & 110 & $\mathrm{SiL}$ & 1.41 & 46.79 & 18.42 & 0.234 & 0.089 & 0.145 \\
\hline Ikwo & 90 & 200 & 290 & 520 & 190 & $\mathrm{SiL}$ & 1.38 & 47.92 & 20.86 & 0.241 & 0.117 & 0.124 \\
\hline Mean & 131.7 & 300.0 & 431.7 & 421.7 & 146.7 & & 1.41 & 46.91 & 19.55 & 0.26 & 0.11 & 0.15 \\
\hline $\mathrm{CV}(\%)$ & 64.9 & 33.3 & 41 & 39.4 & 27.6 & & 1.8 & 2.00 & 6.3 & 16.3 & 16.5 & 21.4 \\
\hline SE & 85.5 & 100 & 176.9 & 166 & 40.4 & & 0.025 & 0.95 & 1.23 & 0.04 & 0.018 & 0.03 \\
\hline $\begin{array}{c}\text { Grand } \\
\text { mean }\end{array}$ & 124.2 & 315.0 & 447.5 & 415.8 & 136.7 & & 1.34 & 49.49 & 19.33 & 0.25 & 0.115 & 0.136 \\
\hline CV (\%) & 51.4 & 41.6 & 39.2 & 39.5 & 12.2 & & 2.7 & 2.67 & 5.6 & 12.2 & 12.1 & 17 \\
\hline SE & 63.8 & 131.1 & 175.4 & 165.3 & 0.03 & & 0.04 & 1.34 & 1.08 & 0.03 & 0.01 & 0.02 \\
\hline
\end{tabular}

$\mathrm{SE}=$ standard error, $\mathrm{CV}=$ Coefficient of variation. $\mathrm{CV}$ rating: $0-15=$ low, $15-35=$ medium, $<35=$ high. 
There was medium variation in the $\mathrm{CS}$ and $\mathrm{Cl}$, content in the three locations and low variations in Bulk density, total porosity, moisture content field capacity, permanent wilting point and AWC while high variations were observed in FC, TS and Si.

At 20 - $40 \mathrm{~cm}$ depth, CS, FS, TS and Si ranged from 75 - 230, 200 - 400, 290 $\mathrm{g} / \mathrm{kg}$ respectively. Clay content ranged from $110-190 \mathrm{~g} / \mathrm{kg}$ while bulk density in the three locations ranged within $1.38-1.43 \mathrm{~g} / \mathrm{cm}^{3}$. Soil total porosity and moisture content ranged from $46.03 \%-47.92 \%$ and $18.42 \%-20.86 \%$, respectively. Filed capacity, PWP and AWC ranged from $0.234-0.311,0.089-0.123$ and $0.124-0.188 \mathrm{~g} / \mathrm{kg}$ respectively. There were low variations in bulk density, total porosity, moisture content, FC and PWP while there were moderated variations in FS, $\mathrm{Cl}$, and AWC. High variations were observed in CS, TS, and Si. Comparing the two sampling depth, there were low variability in the $\mathrm{Cl}$, bulk density, total porosity, moisture content, FC, and PWP while medium variability occurred in AWC and high variability occurred in CS, FS, FS and Si. These variations in the physical properties in the three locations could be attributed to parent materials, climatic influences and land management.

\subsection{Soil Chemical Properties in Ebonyi State}

The chemical properties of soil in Akaeze, Agbaja and Ikwo in Ebonyi State are presented in Table 3. Results showed that at $0-20 \mathrm{~cm}$ depth, the soils are acidic with $\mathrm{Ph}$ in water ranging from 3.8 to 4.4 and $4.7-5.3$ in $\mathrm{KCl}$. Organic carbon ranged from $9.20-26.6 \mathrm{~g} / \mathrm{kg}$ while total nitrogen ranged from $1.1-2.5 \mathrm{~g} / \mathrm{kg}$. Exchangeable bases were low with total exchangeable bases ranging from 2.9 - 3.41 $\mathrm{cmol} / \mathrm{kg}$. Total exchangeable acidity in the three locations ranged from 2.14 $6.66 \mathrm{cmol} / \mathrm{kg}$ while the effective cation exchange capacity was highest at Ikwo location. ACEC ranged from $0-15.82 \mathrm{cmol} / \mathrm{kg}$. Base saturation was had the highest value at Akaeze location and ranged from $33.86 \%-57.53 \%$. Available phosphorus ranged from $3.2-16.3 \mathrm{mg} / \mathrm{kg}$. At $20-40 \mathrm{~cm}$ sampling depth, there was a decrease in the value of soil $\mathrm{pH}$ when compared to $0-20 \mathrm{~cm}$ sampling depth. Organic carbon ranged from $8.80-14.8 \mathrm{~g} / \mathrm{kg}$. Total $\mathrm{N}$ was low and ranged from 0.6 - $0.9 \mathrm{~g} / \mathrm{kg}$. Exchangeable cations ( $\mathrm{Ca}, \mathrm{Mg}, \mathrm{K}$ and $\mathrm{Na}$ ) were low with the highest total exchangeable bases found at Ikwo location. Total exchangeable acidity ranged from $1.94-6.60 \mathrm{cmol} / \mathrm{kg}$. Highest effective cation exchange capacity was found at Ikwo location and ranged from $3.06-8.84 \mathrm{cmol} / \mathrm{kg}$ Akaeze had the highest value of AECE (14.60 cmol/ $/ \mathrm{kg})$ base saturation (39.0\%). Available P ranged from $1.2-12.8 \mathrm{mg} / \mathrm{kg}$.

According to [15], at $0-20 \mathrm{~cm}$ depth, there were low variability in soil $\mathrm{pH}$ and exchangeable $\mathrm{H}$ while there were medium variation in exchangeable $\mathrm{Ca}$, and base saturation. High variability occurred in $\mathrm{OC}, \mathrm{OM}$, total $\mathrm{N}$, exchangeable $\mathrm{Mg}$, $\mathrm{K}, \mathrm{Na}, \mathrm{TEA}, \mathrm{TEB}, \mathrm{ACEC}$, and available P. At $20-40 \mathrm{~cm}$ depth, low variations occurred in soil $\mathrm{pH}$, medium variability was observed in organic matter and organic carbon, total $\mathrm{N}$, exchangeable $\mathrm{Na}, \mathrm{TEB}, \mathrm{ACEC}$ and base saturation while other chemical properties exhibited high variability. As was noted in soil physical properties, at $0-40 \mathrm{~cm}$ depth, there were variations in soil chemical properties. 
Table 3. Chemical properties of soils of Ebonyi State.

\begin{tabular}{|c|c|c|c|c|c|c|c|c|c|c|c|c|c|c|c|c|c|}
\hline \multirow{2}{*}{ Location } & \multirow{2}{*}{$\begin{array}{c}\mathrm{pH} \\
(\mathrm{KCl})\end{array}$} & \multirow{2}{*}{$\begin{array}{c}\mathrm{pH} \\
\left(\mathrm{H}_{2} \mathrm{O}\right)\end{array}$} & OC & $\mathrm{OM}$ & TN & $\mathrm{Ca}$ & $\mathrm{Mg}$ & $\mathrm{K}$ & $\mathrm{Na}$ & TEB & $\mathrm{H}$ & $\mathrm{Al}$ & TEA & ECEC & ACEC & Bsat & Av.P \\
\hline & & & $\mathrm{g} / \mathrm{kg}$ & $\mathrm{g} / \mathrm{kg}$ & $\mathrm{g} / \mathrm{kg}$ & \multicolumn{10}{|c|}{$\mathrm{Cmol} / \mathrm{kg}$} & $\%$ & $\mathrm{Mg} / \mathrm{kg}$ \\
\hline \multicolumn{18}{|c|}{ Sampling depth $(0-20 \mathrm{~cm})$} \\
\hline Akaeze & 4.4 & 5.3 & 17.3 & 29.82 & 1.3 & 1.1 & 1.2 & 0.4 & 0.22 & 2.9 & 1.02 & 1.18 & 2.14 & 5.04 & 15.82 & 57.53 & 3.2 \\
\hline Agbaja & 4 & 4.9 & 26.6 & 45.85 & 2.5 & 1.4 & 0.6 & 0.5 & 0.52 & 3.02 & 1.41 & 2.21 & 3.62 & 6.64 & 0 & 45.48 & 8.6 \\
\hline Ikwo & 3.8 & 4.7 & 9.2 & 15.86 & 1.1 & 1.6 & 1.4 & 0.21 & 0.2 & 3.41 & 2.72 & 3.94 & 6.66 & 10.07 & 14.78 & 33.86 & 16.3 \\
\hline Mean & 4.07 & 4.97 & 17.70 & 30.51 & 1.63 & 1.37 & 1.07 & 0.37 & 0.31 & 3.11 & 1.72 & 2.44 & 4.14 & 7.25 & 10.20 & 45.62 & 9.37 \\
\hline $\mathrm{CV}(\%)$ & 7.50 & 6.20 & 49.20 & 49.20 & 46.40 & 18.40 & 39.00 & 38.80 & 57.20 & 55.70 & 8.60 & 51.90 & 57.10 & 35.30 & 86.80 & 25.90 & 70.30 \\
\hline SE & 0.31 & 0.33 & 8.71 & 15.01 & 0.76 & 0.25 & 9,42 & 0.15 & 0.18 & 2.30 & 0.27 & 0.89 & 1.39 & 2.57 & 8.85 & 11.84 & 6.58 \\
\hline \multicolumn{18}{|c|}{ Sampling depth $(20-40 \mathrm{~cm})$} \\
\hline Akaeze & 4 & 5 & 14.8 & 25.51 & 0.8 & 0.6 & 0.8 & 0.29 & 0.19 & 1.88 & 1.24 & 1.7 & 2.94 & 4.82 & 14.6 & 39 & 1.2 \\
\hline Agbaja & 4.1 & 5.1 & 9.4 & 16.2 & 0.9 & 0.4 & 0.2 & 0.4 & 0.12 & 1.12 & 0.61 & 1.33 & 1.94 & 3.06 & 10.12 & 36.6 & 6.3 \\
\hline Ikwo & 3.7 & 4.8 & 8.8 & 15.17 & 0.6 & 1.2 & 0.8 & 0.13 & 0.11 & 2.24 & 2.7 & 3.9 & 6.6 & 8.84 & 14.36 & 25.33 & 12.8 \\
\hline Mean & 3.93 & 4.97 & 11.00 & 18.96 & 0.77 & 0.73 & 0.60 & 0.27 & 0.14 & 1.75 & 1.52 & 2.31 & 3.83 & 5.57 & 13.03 & 33.64 & 6.77 \\
\hline CV (\%) & 5.3 & 3.1 & 30 & 30 & 19.9 & 56.8 & 57.7 & 49.7 & 31.1 & 32.7 & 70.7 & 60.1 & 64.1 & 53.2 & 19.3 & 21.7 & 86.9 \\
\hline SE & 0.21 & 0.52 & 3.3 & 5.7 & 0.15 & 0.42 & 0.35 & 0.13 & 0.04 & 0.57 & 1.7 & 1.39 & 2.45 & 2.96 & 2.52 & 7.3 & 5.81 \\
\hline Grand mean & 4.00 & 4.97 & 14.35 & 24.74 & 1.20 & 1.05 & 0.83 & 0.32 & 0.23 & 2.43 & 1.62 & 2.38 & 3.98 & 6.41 & 11.61 & 39.63 & 8.07 \\
\hline CV (\%) & 6.5 & 4.9 & 45.9 & 45.9 & 45.5 & 32.8 & 4.6 & 44 & 57.6 & 18.4 & 61 & 58.6 & 59.7 & 43.3 & 56 & 24.8 & 77 \\
\hline SE & 0.26 & 0.24 & 6.59 & 11.36 & 0.55 & 0.34 & 0.38 & 0.14 & 0.13 & 0.44 & 0.99 & 1.39 & 2.38 & 2.77 & 6.51 & 9.83 & 6.21 \\
\hline
\end{tabular}

\subsection{Soil Physical Properties of Akaeze in Ebonyi State}

The physical properties of soil in Akaeze are presented in Table 4. Results showed that there is an increase in the coarse sand (CS), fine sand (FS), total sand (FS) and clay (CL) content down the pit. The mean value of CS, FS, TS and Cl were $168,225,393$, and $350 \mathrm{~g} / \mathrm{kg}$ respectively. The textural class of the soil from A to Bt2 horizon was clay loam. There was a decrease in the bulk density and an increase in soil total porosity down the epipedon. Moisture content (Ǿm), field capacity (FC), permanent wilting point (PWP) and AWC did not follow a particular sequence. There were low variations on soil bulk density, total porosity, moisture content, filed capacity and PWP within the horizon. Medium variations were observed in total sand (TS) and AWC while high variations occurred in the coarse sand, fine sand and silt fraction.

\subsection{Soil Chemical Properties of Akaeze in Ebonyi State}

The chemical properties of Akaeze soil in Ebonyi State are presented in Table 5. The soil was moderately acidic with low variability. High variations were observed in the organic carbon, organic matter and total nitrogen content within the horizons. The mean values of organic carbon, organic matter and total nitrogen were $11.68,20.12$ and $0.83 \mathrm{~g} / \mathrm{kg}$ respectively. According to [6] rating, 
Table 4. Soil physical properties of Akaeze soils in Ebonyi State.

\begin{tabular}{|c|c|c|c|c|c|c|c|c|c|c|c|c|c|}
\hline \multirow{2}{*}{ Horizon } & \multirow{2}{*}{$\begin{array}{c}\text { Depth } \\
(\mathrm{cm})\end{array}$} & CS & FS & TS & $\mathrm{Si}$ & $\mathrm{Cl}$ & \multirow{2}{*}{$\mathrm{TC}$} & \multirow{2}{*}{$\begin{array}{c}\text { BD } \\
\mathrm{g} / \mathrm{cm}^{3}\end{array}$} & \multirow{2}{*}{$\begin{array}{l}\text { TP } \\
\%\end{array}$} & \multirow{2}{*}{$\begin{array}{c}\emptyset \mathrm{m} \\
\%\end{array}$} & \multirow{2}{*}{$\begin{array}{c}\mathrm{FC} \\
\mathrm{g} / \mathrm{kg}\end{array}$} & \multirow{2}{*}{$\begin{array}{l}\text { PWP } \\
\text { g/kg }\end{array}$} & \multirow{2}{*}{$\begin{array}{l}\text { AWC } \\
\mathrm{g} / \mathrm{kg}\end{array}$} \\
\hline & & $\mathrm{g} / \mathrm{kg}$ & $\mathrm{g} / \mathrm{kg}$ & $\mathrm{g} / \mathrm{kg}$ & $\mathrm{g} / \mathrm{kg}$ & $\mathrm{g} / \mathrm{kg}$ & & & & & & & \\
\hline A & $0-13$ & 100 & 200 & 300 & 400 & 300 & CL & 1.27 & 52.07 & 20.28 & 0.258 & 0.118 & 0.14 \\
\hline $\mathrm{AB}$ & $13-40$ & 150 & 250 & 400 & 200 & 400 & CL & 1.39 & 47.54 & 22.54 & 0.332 & 0.121 & 0.211 \\
\hline Bt1 & $40-60$ & 200 & 230 & 430 & 200 & 370 & CL & 1.48 & 44.15 & 21.82 & 0.263 & 0.119 & 0.144 \\
\hline \multirow[t]{4}{*}{$\mathrm{Bt} 2$} & $60+$ & 220 & 220 & 440 & 200 & 360 & CL & 0.0 & 0.0 & 23.1 & 0.0 & 0.0 & 0.0 \\
\hline & Mean & 168 & 225 & 393 & 250 & 358 & & 1.04 & 35.94 & 21.94 & 0.21 & 0.09 & 0.12 \\
\hline & CV (\%) & 32.1 & 93 & 16.3 & 40 & 11.7 & & 7.6 & 8.3 & 5.6 & 14.5 & 1.3 & 24.2 \\
\hline & SE & 53.8 & 20.8 & 64 & 100 & 41.9 & & 0.11 & 3.97 & 1.22 & 0.04 & 0.001 & 0.04 \\
\hline
\end{tabular}

$\mathrm{SE}=$ standard error, $\mathrm{CV}=$ coefficient of variation.

Table 5. Soil chemical properties of Akaeze soils in Ebonyi State.

\begin{tabular}{|c|c|c|c|c|c|c|c|c|c|c|c|c|c|c|c|c|c|c|}
\hline & Depth & $\mathrm{pH}$ & $\mathrm{pH}$ & OC & $\mathrm{OM}$ & TN & $\mathrm{Ca}$ & $\mathrm{Mg}$ & $\mathrm{K}$ & $\mathrm{Na}$ & TEB & $\mathrm{H}$ & $\mathrm{Al}$ & TEA & ECEC & ACEC & Bsat & Av. $P$ \\
\hline & $(\mathrm{cm})$ & $(\mathrm{KCl})$ & $\left(\mathrm{H}_{2} \mathrm{O}\right)$ & $\mathrm{g} / \mathrm{kg}$ & $\mathrm{g} / \mathrm{kg}$ & $\mathrm{g} / \mathrm{kg}$ & \multicolumn{10}{|c|}{$\mathrm{Cmol} / \mathrm{kg}$} & $\%$ & $\mathrm{Mg} / \mathrm{kg}$ \\
\hline A & $0-13$ & 4.5 & 5.4 & 19.2 & 33.1 & 1.6 & 1.2 & 1.6 & 0.43 & 0.27 & 3.5 & 0.85 & 1.1 & 1.95 & 5.45 & 16.76 & 64.22 & 3.8 \\
\hline $\mathrm{AB}$ & $13-40$ & 4.2 & 5.1 & 16 & 27.58 & 0.9 & 0.8 & 1.1 & 0.33 & 0.21 & 2.44 & 1.22 & 1.55 & 2.77 & 5.21 & 16.32 & 46.83 & 1.7 \\
\hline Bt1 & $40-60$ & 4.6 & 5.6 & 8.3 & 14.3 & 0.6 & 1.4 & 1.4 & 0.46 & 0.31 & 3.57 & 1.08 & 1.13 & 2.21 & 5.78 & 17.2 & 61.76 & 3.7 \\
\hline \multirow[t]{4}{*}{ Bt2 } & $60+$ & 5 & 5.9 & 3.2 & 5.51 & 0.2 & 0.4 & 0.8 & 0.52 & 0.25 & 1.97 & 0.96 & 1.27 & 2.23 & 4.2 & 12.88 & 46.9 & 0 \\
\hline & Mean & 4.58 & 5.50 & 11.68 & 20.12 & 0.83 & 0.95 & 1.23 & 0.44 & 0.26 & 2.87 & 1.03 & 1.26 & 2.29 & 5.16 & 15.79 & 54.93 & 2.30 \\
\hline & CV (\%) & 8.7 & 7.3 & 55.2 & 55.2 & 42.6 & 53 & 24.5 & 22.3 & 19.4 & 28.7 & 12.7 & 16.9 & 13.9 & 15.5 & 14.5 & 15.7 & 80.5 \\
\hline & SE & 0.4 & 0.4 & 6.44 & 11.11 & 0.35 & 0.5 & 0.3 & 0.1 & 0.05 & 0.82 & 0.13 & 0.21 & 0.32 & 0.8 & 2.28 & 8.6 & 1.85 \\
\hline
\end{tabular}

$\mathrm{SE}=$ standard error, $\mathrm{CV}=$ coefficient of variation.

exchangeable $\mathrm{Ca}, \mathrm{Mg}, \mathrm{K}$ and $\mathrm{Na}$ were very low with moderate variability. Total exchangeable acidity increased with increase in depth while effective cation exchange capacity was very low according to [6] rating. However, base saturation was moderate and available phosphorus was low. The morphological characteristics of the soil as shown in Table 5 showed a dark brown colour on A horizon, yellowish brown to light gray colour at the $\mathrm{AB}$ and Bt1 horizon while at BT 2, the colour is ponded. The structures consisted of coarse sub angular block with firm consistency. The boundary was gradual and smooth.

\subsection{Soil Physical Properties of Agbaja Soils in Izzi LGA in Ebonyi State}

The physical properties of Agbaja soils in Ebonyi State are presented in Table 6 . Results showed that the mean value of CS, FS, TS, Si and Cl were 112, 130, 242, 583 and $192 \mathrm{~g} / \mathrm{kg}$ respectively. The textural classes of the soil from A to Bt4 horizons were silt loam and clay. Unlike in Akaeze soil, there was an increase in the bulk density and a decrease in soil total porosity from A to Bt4 horizons. 
Table 6. Soil physical properties of Agbaja soils in Izzi LGA in Ebonyi State.

\begin{tabular}{|c|c|c|c|c|c|c|c|c|c|c|c|c|c|}
\hline \multirow{2}{*}{ Horizon } & \multirow{2}{*}{$\begin{array}{l}\text { Depth } \\
(\mathrm{cm})\end{array}$} & \multirow{2}{*}{$\begin{array}{c}\mathrm{CS} \\
\mathrm{g} / \mathrm{kg}\end{array}$} & \multirow{2}{*}{$\begin{array}{c}\mathrm{FS} \\
\mathrm{g} / \mathrm{kg}\end{array}$} & \multirow{2}{*}{$\begin{array}{c}\text { TS } \\
\mathrm{g} / \mathrm{kg}\end{array}$} & \multirow{2}{*}{$\begin{array}{c}\mathrm{Si} \\
\mathrm{g} / \mathrm{kg}\end{array}$} & \multirow{2}{*}{$\begin{array}{c}\mathrm{Cl} \\
\mathrm{g} / \mathrm{kg}\end{array}$} & \multirow{2}{*}{$\mathrm{TC}$} & \multirow{2}{*}{$\begin{array}{c}\mathrm{BD} \\
\mathrm{g} / \mathrm{cm}^{3}\end{array}$} & \multirow{2}{*}{$\begin{array}{l}\text { TP } \\
\%\end{array}$} & \multirow{2}{*}{$\begin{array}{c}\emptyset_{\mathrm{m}} \\
\%\end{array}$} & \multirow{2}{*}{$\begin{array}{c}\mathrm{FC} \\
\mathrm{g} / \mathrm{kg}\end{array}$} & \multirow{2}{*}{$\begin{array}{c}\text { PWP } \\
\mathrm{g} / \mathrm{kg}\end{array}$} & \multirow{2}{*}{$\begin{array}{l}\text { AWC } \\
\mathrm{g} / \mathrm{kg}\end{array}$} \\
\hline & & & & & & & & & & & & & \\
\hline A & $0-14$ & 130 & 130 & 260 & 700 & 40 & $\mathrm{SiL}$ & 1.29 & 51.32 & 18.68 & 0.231 & 0.123 & 0.108 \\
\hline $\mathrm{AB}$ & $14-37$ & 80 & 120 & 200 & 720 & 80 & $\mathrm{SiL}$ & 1.39 & 47.54 & 18.8 & 0.233 & 0.121 & 0.112 \\
\hline Bt1 & $37-60$ & 100 & 200 & 300 & 620 & 80 & $\mathrm{SiL}$ & 1.41 & 46.79 & 19.2 & 0.221 & 0.119 & 0.102 \\
\hline Bt2 & $60-108$ & 100 & 100 & 200 & 450 & 350 & $\mathrm{Cl}$ & 1.48 & 44.15 & 23 & 0.235 & 0.123 & 0.112 \\
\hline Bt3 & $108-130$ & 130 & 100 & 230 & 650 & 220 & $\mathrm{SiL}$ & 1.59 & 40 & 21.22 & 0.232 & 0.121 & 0.111 \\
\hline \multirow[t]{4}{*}{ Bt 4} & $130-190$ & 130 & 130 & 260 & 360 & 380 & $\mathrm{Cl}$ & 1.63 & 38.49 & 22.18 & 0.236 & 0.125 & 0.111 \\
\hline & Mean & 112 & 130 & 242 & 583 & 192 & & 1.47 & 44.72 & 20.51 & 0.23 & 0.12 & 0.11 \\
\hline & CV (\%) & 19.1 & 28.4 & 16.2 & 24.9 & 77.1 & & 8.8 & 10.8 & 9.1 & 2.3 & 1.70 & 3.6 \\
\hline & SE & 21.37 & 36.9 & 39.2 & 145.4 & 147.8 & & 0.128 & 4.84 & 1.87 & 0.005 & 0.002 & 0.004 \\
\hline
\end{tabular}

$\mathrm{SE}=$ standard error, $\mathrm{CV}=$ coefficient of variation.

Moisture content (Ǿm) increased down the depth. The mean values of FC, PWP and AWE were $0.23,0.12$ and $0.11 \mathrm{~g} / \mathrm{kg}$ respectively. There was low variability in soil bulk density, total porosity, moisture content, PWP and AWC while medium variation existed in coarse sand, total sand and silt and high variations existed in clay.

\subsection{Soil Chemical Properties of Agbaja Soils in Izzi LGA in Ebonyi State}

The chemical properties of Agbaja soil in Izzi local Government Area, Ebonyi State are presented in Table 7. Like in Akaeze, the soil was strongly acidic according to [16] rating with low variation. There was a decrease in the concentration of organic carbon, organic matter and total nitrogen from epipedon down the subsoil. This could be attributed to litter falls that after decomposition, increases the organic matter in the soil. Low variations also were observed in these properties from A to Bt4 horizon. However, organic matter and total nitrogen were low according to [16] rating. Exchangeable Ca was moderate while exchangeable $\mathrm{Mg}, \mathrm{K}$ and $\mathrm{Na}$ were low based on [6] rating. There were high variation in exchangeable $\mathrm{Ca}, \mathrm{Mg}$ and $\mathrm{K}$ while $\mathrm{Na}$ was medium in variation from $\mathrm{A}$ to $\mathrm{Bt} 4$ horizons. Effective cation exchange capacity was low while base saturation was medium. The concentration of available phosphorus was low according to critical limits for interpreting soil fertility levels [6]. Available phosphorus was also low with high variability. Low concentrations of exchangeable bases and effective cation exchange capacity could be attributed to low organic matter content since organic matter acts as a reservoir for storing nutrient elements. Also, the acidity of the soil from A to Bt4 horizon could have influenced the concentration of exchangeable nutrients since soil $\mathrm{pH}$ influences the availability of plant nutrient elements. 
Table 7. Soil chemical properties of Agbaja soils in Izzi LGA in Ebonyi State.

\begin{tabular}{|c|c|c|c|c|c|c|c|c|c|c|c|c|c|c|c|c|c|c|}
\hline Horimon & Depth & $\mathrm{pH}$ & pH & OC & $\mathrm{OM}$ & TN & $\mathrm{Ca}$ & $\mathrm{Mg}$ & K & $\mathrm{Na}$ & TEB & $\mathrm{H}$ & $\mathrm{Al}$ & TEA & ECEC & ACEC & Bsat & Av. P \\
\hline & (cm) & $(\mathrm{KCl})$ & $\left(\mathrm{H}_{2} \mathrm{O}\right)$ & $\mathrm{g} / \mathrm{kg}$ & $\mathrm{g} / \mathrm{kg}$ & $\mathrm{g} / \mathrm{kg}$ & \multicolumn{10}{|c|}{$\mathrm{Cmol} / \mathrm{kg}$} & $\%$ & $\mathrm{Mg} / \mathrm{kg}$ \\
\hline A & $0-14$ & 4.1 & 5 & 29 & 49.99 & 2.8 & 1.8 & 0.8 & 0.8 & 0.2 & 3.6 & 1.3 & 1.9 & 3.2 & 6.8 & 17.24 & 52.9 & 8.1 \\
\hline $\mathrm{AB}$ & $14-37$ & 4.2 & 5.2 & 10 & 17.24 & 1.1 & 0.8 & 0.3 & 0.2 & 0.16 & 1.46 & 0.5 & 1.04 & 1.54 & 3 & 10 & 48.66 & 7.7 \\
\hline Bt1 & $37-60$ & 4.3 & 5.3 & 6 & 10.34 & 0.8 & 1.1 & 0.4 & 0.44 & 0.22 & 2.17 & 0.8 & 1.13 & 1.93 & 4.1 & 10.43 & 52.92 & 1.69 \\
\hline Bt2 & $60-108$ & 4.5 & 5.6 & 3 & 5.17 & 0.5 & 1.4 & 0.4 & 0.46 & 0.18 & 2.41 & 1 & 1.31 & 2.31 & 4.72 & 10.72 & 51.05 & 4.36 \\
\hline Bt3 & $108-130$ & 4.3 & 5.3 & 2 & 3.44 & 0.3 & 1 & 0.3 & 0.42 & 0.16 & 1.88 & 0.74 & 1 & 1.74 & 3.62 & 9.88 & 51.93 & 5.22 \\
\hline \multirow[t]{4}{*}{ Bt4 } & $130-190$ & 4.2 & 5.1 & 1 & 1.72 & 0.1 & 0.6 & 0.2 & 0.38 & 0.12 & 1.3 & 0.82 & 0.54 & 1.36 & 2.66 & 6.38 & 48.97 & 1.7 \\
\hline & Mean & 4.27 & 5.25 & 8.50 & 14.65 & 0.93 & 1.12 & 0.40 & 0.45 & 0.17 & 2.14 & 0.86 & 1.15 & 2.01 & 4.15 & 10.78 & 51.07 & 4.80 \\
\hline & CV (\%) & 3.2 & 3.9 & 124.2 & 124.3 & 105.1 & 38.6 & 52.4 & 43.4 & 20.2 & 39.8 & 31.3 & 38.7 & 33.2 & 36 & 32.8 & 3.7 & 58.2 \\
\hline & SE & 0.14 & 0.21 & 10.56 & 18.2 & 0.98 & 0.43 & 0.21 & 0.195 & 0.04 & 0.83 & 0.27 & 0.44 & 0.66 & 1.49 & 3.54 & 1.88 & 2.79 \\
\hline
\end{tabular}

$\mathrm{SE}=$ standard error, $\mathrm{CV}=$ coefficient of variation.

\subsection{Soil Physical Properties of Ikwo LGA in Ebonyi State}

The physical properties of soil of Ikwo Local Government Area in Ebonyi State are presented in Table 8. Results showed that the mean value of CS, FS, TS, Si and $\mathrm{Cl}$ were $43,182,225,380$ and $395 \mathrm{~g} / \mathrm{kg}$ respectively. There were variations in the textural classes of the soil from A to Bt3 horizons. The bulk density, moisture content, PWP and AWC increased from A to Bt3 horizon. Similar trend was observed in Izzi, Agbaja soil. There were low variability in soil bulk density, total porosity, moisture content and PWPW and medium variability in AWC, total sand, silt fraction and fine sand while high variability occurred in coarse sand.

\subsection{Soil Chemical Properties of Ikwo LGA in Ebonyi State}

The chemical properties of soil of Ikwo Local Government Area, Ebonyi State are presented in Table 9. The soils are strongly acidic according to [16] rating with low variation. The mean values of organic carbon, organic matter, and total nitrogen were $4.74,8.18$ and $0.52 \mathrm{~g} / \mathrm{kg}$ respectively. These values according to [6] rating was low and the highest values were recorded at the epipedon. This could be attributed to litter decomposition and expected microbial population that increases organic matter decomposition and nutrient transformation. Exchangeable $\mathrm{Ca}, \mathrm{Mg}, \mathrm{K}$ and $\mathrm{Na}$ were low and the total exchangeable cations were medium in variability. Exchangeable $\mathrm{Ca}$ decreased with increase in depth. There were low variability in total exchangeable acidity, effective cation exchange capacity, base saturation and available phosphorus. The concentration of base saturation and available phosphorus were low based on [16] rating.

\subsection{Relationship between Edaphic Factors and Maize and Cassava Yield in Ebonyi State}

The results interestingly showed that there is a relationship between edaphic factors 
Table 8. Soil physical properties of Ikwo LGA in Ebonyi State.

\begin{tabular}{|c|c|c|c|c|c|c|c|c|c|c|c|c|c|}
\hline \multirow{2}{*}{ Horizon } & \multirow{2}{*}{$\begin{array}{l}\text { Depth } \\
(\mathrm{cm})\end{array}$} & CS & FS & TS & $\mathrm{Si}$ & $\mathrm{Cl}$ & \multirow{2}{*}{$\mathrm{TC}$} & $\mathrm{BD}$ & TP & $\emptyset \mathrm{m}$ & FC & PWP & AWC \\
\hline & & $\mathrm{g} / \mathrm{kg}$ & $\mathrm{g} / \mathrm{kg}$ & $\mathrm{g} / \mathrm{kg}$ & $\mathrm{g} / \mathrm{kg}$ & $\mathrm{g} / \mathrm{kg}$ & & $\mathrm{g} / \mathrm{cm}^{3}$ & $\%$ & $\%$ & $\mathrm{~g} / \mathrm{kg}$ & $\mathrm{g} / \mathrm{kg}$ & $\mathrm{g} / \mathrm{kg}$ \\
\hline A & $0-7$ & 20 & 170 & 190 & 480 & 330 & $\mathrm{~L}$ & 1.2 & 54.71 & 20.56 & 0.243 & 0.122 & 0.121 \\
\hline $\mathrm{AB}$ & $7-39$ & 16 & 110 & 126 & 490 & 384 & CL & 1.34 & 49.43 & 21.62 & 0.256 & 0.116 & 0.14 \\
\hline Bt1 & $39-88$ & 36 & 220 & 256 & 330 & 414 & CL & 1.41 & 46.79 & 22.86 & 0.266 & 0.119 & 0.147 \\
\hline Bt2 & $88-130$ & 22 & 200 & 222 & 340 & 438 & C & 1.59 & 40 & 22.92 & 0.333 & 0.141 & 0.192 \\
\hline \multirow[t]{4}{*}{$\mathrm{Bt} 3$} & $130-175$ & 120 & 210 & 330 & 260 & 410 & $\mathrm{C}$ & 1.63 & 38.49 & 21.88 & 0.258 & 0.115 & 0.143 \\
\hline & Mean & 43 & 182 & 225 & 380 & 395 & & 1.43 & 45.88 & 21.97 & 0.27 & 0.12 & 0.15 \\
\hline & CV (\%) & 102.4 & 24.4 & 33.7 & 26.5 & 10.4 & & 12.4 & 14.6 & 4.4 & 13.1 & 8.70 & 17.7 \\
\hline & SE & 43.8 & 44.4 & 75.9 & 100.7 & 41.2 & & 0.18 & 6.72 & 0.97 & 0.04 & 0.001 & 0.03 \\
\hline
\end{tabular}

Table 9. Soil chemical properties of Ikwo LGA in Ebonyi State.

\begin{tabular}{|c|c|c|c|c|c|c|c|c|c|c|c|c|c|c|c|c|c|c|}
\hline Homimon & Depth & $\mathrm{pH}$ & $\mathrm{pH}$ & OC & $\mathrm{OM}$ & TN & $\mathrm{Ca}$ & $\mathrm{Mg}$ & $\mathrm{K}$ & $\mathrm{Na}$ & TEB & $\mathrm{H}$ & $\mathrm{Al}$ & TEA & ECEC & ACEC & Bsat & Av. $P$ \\
\hline & $(\mathrm{cm})$ & $(\mathrm{KCl})$ & $\left(\mathrm{H}_{2} \mathrm{O}\right)$ & $\mathrm{g} / \mathrm{kg}$ & $\mathrm{g} / \mathrm{kg}$ & $\mathrm{g} / \mathrm{kg}$ & \multicolumn{10}{|c|}{$\mathrm{Cmol} / \mathrm{kg}$} & $\%$ & $\mathrm{Mg} / \mathrm{kg}$ \\
\hline A & $0-7$ & 4 & 4.9 & 10.4 & 18 & 1.3 & 2.2 & 1.8 & 0.2 & 0.4 & 4.6 & 2.5 & 3.78 & 6.28 & 10.88 & 15.06 & 42.27 & 18.86 \\
\hline $\mathrm{AB}$ & $7-39$ & 4 & 5.1 & 5.8 & 9.8 & 0.7 & 1.6 & 1.2 & 0.1 & 0.3 & 3.2 & 2.5 & 3.9 & 6.4 & 9.6 & 14.46 & 33.33 & 18.2 \\
\hline Bt1 & $39-88$ & 4.1 & 5.2 & 3.7 & 6.4 & 0.3 & 1.4 & 1 & 0.2 & 0.3 & 2.9 & 2.0 & 3.0 & 5.0 & 7.9 & 12.68 & 36.7 & 18.5 \\
\hline Bt2 & $88-130$ & 4.1 & 5.1 & 2.3 & 4.1 & 0.2 & 1.2 & 1.1 & 0.1 & 0.4 & 2.8 & 2 & 3.7 & 5.7 & 8.5 & 13.54 & 32.94 & 18.16 \\
\hline \multirow[t]{4}{*}{ Bt3 } & $130-175$ & 4.0 & 5.0 & 1.5 & 2.6 & 0.1 & 1.8 & 1.4 & 0.1 & 0.2 & 3.5 & 3.08 & 3.08 & 6.16 & 9.66 & 14.5 & 36.23 & 16.24 \\
\hline & Mean & 4.04 & 5.06 & 4.74 & 8.18 & 0.52 & 1.64 & 1.3 & 0.14 & 0.32 & 3.4 & 2.416 & 3.49 & 5.91 & 9.30 & 14.05 & 36.29 & 17.99 \\
\hline & CV (\%) & 1.4 & 2.3 & 75.1 & 74.9 & 94.6 & 23.5 & 24.3 & 39.1 & 26.1 & 21.3 & 18.5 & 12 & 9.7 & 12.4 & 6.7 & 10.3 & 5.7 \\
\hline & SE & 0.05 & 0.11 & 3.56 & 6.12 & 0.49 & 0.37 & 0.32 & 0.05 & 0.08 & 0.73 & 0.45 & 0.42 & 0.57 & 1.15 & 0.97 & 3.74 & 1.02 \\
\hline
\end{tabular}

and yield of the arable crops in the state. For example, cassava yield significantly correlated negatively with some chemical properties like base saturation $(-0.5296)$ at 0.05 probability level, exchangeable $\mathrm{Ca}$ and $\mathrm{Na}$ at 0.01 probability level, organic matter and organic carbon at 0.05 probability level, total exchangeable bases, total nitrogen and total porosity at 0.01 probability level but significantly correlated positively with physical properties such as bulk density (0.8637) and available water capacity at 0.01 probability level and 0.05 probability level, respectively.

Similarly, maize yield significantly correlated negatively with the following chemical properties; available phosphorus, total nitrogen, total exchangeable bases, and $\mathrm{Si}$ at 0.05 probability level, and total porosity, and exchangeable $\mathrm{Ca}$ at 0.01 probability level. On the other hand, maize yield significantly correlated positively some physical soil properties such as available water capacity, bulk density and fine sand FC at 0.01 probability level and with coarse sand (CS) at 0.05 probability level. 


\section{Discussions}

This research shows that at $0-20 \mathrm{~cm}$ depth, there was medium variation in the $\mathrm{CS}$ and $\mathrm{Cl}$, content in the three locations and low variations in Bulk density, total porosity, moisture content field capacity, permanent wilting point and AWC while high variations were observed in FC, TS and Si. At $20-40 \mathrm{~cm}$ depth, there were low variations in bulk density, total porosity, moisture content, FC and PWP while there were moderated variations in FS, $\mathrm{Cl}$, and AWC. High variations were observed in CS, TS, and Si. However, this study is in agreement with the research by [17], which reported that the bulk density of sub surface horizons were usually significantly greater than those of surface horizons, since the BD of $0-20 \mathrm{~cm}$ depth is $1.27 \mathrm{~g} / \mathrm{cm}^{3}$ and $20-40 \mathrm{~cm}$ depth is $1.41 \mathrm{~g} / \mathrm{cm}^{3}$. To support this further [18], while assessing the characteristics of soils in the Guinea Savanna zone of Nigeria reported that bulk density increased down the profile, in concord with increase in clay content. Hence, in this study, clay content increased down the profile from $126.7 \mathrm{~kg}$ to $146.7 \mathrm{~kg}$.

[17], reported that volumetric moisture content at field capacity and wilting point increased significantly as sampling depth increased. This is in agreement with this study where $\theta \mathrm{m}$ increased from $19.11 \%$ to $19.55 \%$. Similarly, according to Landon [19], $\mathrm{pH}>8.5=$ very high, $7.0-8.5=$ high, $5.5-7.0=$ medium and $<5.5$ = low. However, results from this research generally show that $\mathrm{pH}$ in water $\left\{\mathrm{pH}\left(\mathrm{H}_{2} 0\right)\right\}$ is always higher than $\mathrm{pH}$ in $\mathrm{KCl}\{\mathrm{pH}(\mathrm{KCl})\}$, hence $\mathrm{pH}\left(\mathrm{H}_{2} 0\right)$ and $\mathrm{pH}$ $(\mathrm{KCl})$ at the two sampling depths are 4.97 to 4.07 and 4.07 to 3.93. These results also give support to the study by Ukaegbu and Akamigbo [20] that recorded a higher $\mathrm{pH}$ in water than $\mathrm{pH}$ in $\mathrm{KCl}(1 \mathrm{~N})$ while working on the soils of the Cross River plains.

Furthermore, [21], reported that such reaction is characteristic of soils in southeastern Nigeria and it is the result of the acidic nature of the parent rocks, coupled with the influence of the leached profile under high annual rainfall condition. [20] [22], reported that total nitrogen is usually highest in the topsoil, decreasing down the profile. To support the results of the previous studies cited here, this research reports high values of total nitrogen at the topsoil, decreasing down the profile. Thus, in this study results show that Akaeze soil total nitrogen ranges from $0.013 \%$ to $0.008 \%$, Agbaja $=0.025 \%$ to $0.009 \%$ and $\mathrm{Ikwo}=0.011 \%$ to $0.006 \%$.

According to [21], the low nitrogen in most of the pedons is a common phenomenon in the soils of Southeastern Nigeria and is as a result of the high nitrogen losses sustained in these soils through leaching of nitrates, as well as the rapid mineralization of organic matter under the isohyperthermic soil temperature regime.

The research also show that in Ebonyi State, the average available Phosphorous of the soils at the two sampling depths are moderate according Landon [19] rating with values of $9.37 \mathrm{mg} / \mathrm{kg}$ and $6.77 \mathrm{mg} / \mathrm{kg}$, respectively. This is in line with the result reported by [22] of moderate concentration of available phosphorous 
(8.64 - $9.61 \mathrm{ppm}$ ) in the topsoils of soils overlying the Coastal Plain Sands of Imo state in southeastern Nigeria.

According to Landon [19] ECEC is used to estimate the potential fertility of the soil, the possible response to fertilizer application and as a rough guide to the types of clay minerals present. According to this study therefore, Ebonyi State has medium values of ECEC with $21.75 \mathrm{cmol} / \mathrm{kg}$ and $16.72 \mathrm{cmol} / \mathrm{kg}$ in the top soils and sub soils, respectively. However, the values of ECEC decrease with increase in depth, which is a common condition with most soil properties in the southeast Nigeria as reported in other studies [23] [24] [25] [26]. This study established that edaphic factors have negative effects on the yield of cassava and maize in Ebonyi State because some soil properties that normally promote crop growth such as total Nitrogen, available phosphorus, organic matter, total exchangeable bases; exchangeable $\mathrm{Ca}$ and $\mathrm{Na}$ are still low in value. Similar case was reported in [16] and [27] where decreased in the yield of arable crops in southeastern Nigeria were attributed to low level of soil nutrient elements in the region.

\section{Conclusions}

The study shows that soils of Ebonyi State had a good correlation with the food crops. This means that soils physico-chemical properties affect crop production in the area, but other factors such as technology, environmental hazards, and farmers' adaptive skill to climatic variations and change can also account for variations recorded respectively in maize and cassava yields in the state. Comparing the two sampling depths, $0-20 \mathrm{~cm}$ and $20-40 \mathrm{~cm}$, there were low variability in the $\mathrm{Cl}$, bulk density, total porosity, moisture content, FC, and PWP while medium variability occurred in AWC and high variability occurred in CS, FS and Si. These variations in the physical properties in the three locations could be attributed to parent materials, climatic influences and land management. The study also shows that at $0-20 \mathrm{~cm}$ depth, the soils are acidic with $\mathrm{pH}$ in water lower than $\mathrm{pH}$ in $\mathrm{KCl}$ but based on [15] rating, there were low variability in the soils' $\mathrm{pH}$ and exchangeable $\mathrm{H}$ at $0-20 \mathrm{~cm}$ depth while medium variability occurred in exchangeable $\mathrm{Ca}$, and base saturation. High variability occurred in $\mathrm{OC}, \mathrm{OM}$, total N, exchangeable Mg, K, Na, TEA, TEB, ACEC, and available P. At $20-40 \mathrm{~cm}$ depth, low variations occurred in soil $\mathrm{pH}$, medium variability was observed in organic matter and organic carbon, total N, exchangeable Na, TEB, ACEC and base saturation while other chemical properties exhibited high variability. As was noted in soil physical properties, at $0-40 \mathrm{~cm}$ depth, there were variations in soil chemical properties.

Furthermore, it was observed that Ebonyi State soil contains some plant nutrient elements that will support crop production. This means that Ebonyi State soils are fertile to an extent as was also reported in [27]. However, the chemical properties of soils in the state are still low according to [6] [16] [19] soil fertility rating. Hence, there is therefore need to boost more the productivity of soils in the State by applying proper amount of nutrients for maximum crop production. 
This is also to support the study by [28] which reported that optimum soil nutrients are sine qua non for sustainable agriculture for food and nutrition security.

\section{Recommendations}

Proper soil management strategy is necessary for the farmers in the state to adopt in order to improve soils qualities for optimum food production. In this case, researchers and extension workers should prove to farmers that application of organic amendments is important for getting higher yield of crops like maize and cassava.

Climate is another physical factor affecting soils quality; therefore, farmers need education and awareness on the climate risks, which reduces soil quality and in turn affects their crops. In other words, farmers' hands-on training is needed in order to produce quality organic manures/fertilizers and application technology.

Ebonyi State government and federal government of Nigeria need to give incentives like organic fertilizers to resource poor farmers which will support growth and development of food crops for yield maximization.

Finally, it is significant to introduce and develop genotypes of crops (such as maize, cassava, etc.) which are adapted to the environment and soils of specific areas for getting sustainably higher yield.

\section{Conflicts of Interest}

The authors declare no conflicts of interest regarding the publication of this paper.

\section{References}

[1] Apata, T.G., Samuel, K.D. and Adeola, A.O. (2009) Analysis of Climate Change Perception and Adaptation among Arable Food Crop Farmers in South Western Nigeria. The International Association of Agricultural Economists 2009 Conference, Beijing, China, 16-22 August 2009.

[2] Agboola, T. and Ojeleye, D. (2007) Climate Change and Food Crop Production in Ibadan, Nigeria. African Crop Science Conference Proceedings, 8, 1423-1433.

[3] Chi-Chung, C., McCarl, B.A. and Schimmelpfennig, D. (2004) Yield Variability as Influenced by Climate: Statistical Investigation. Climate Change, 66, 239-261+204. https://doi.org/10.1023/B:CLIM.0000043159.33816.e5

[4] Lia, R. (1979) Physical Characteristic of Soil in the Tropics. In: Lar, R. and Greenland, D., Eds., Determination and Management, Willey and Sons, London, UK.

[5] Ani, A.O. (2002) Factors Inhibiting Agricultural Projection among Rural Women Farmers in Southern Ebonyi State, Nigeria. Ph.D. Thesis, University of Maiduguri, Nigeria.

[6] FAO (Food and Agricultural Organization) (2006) Guidelines for Soil Description. 4th Edition, Food and Agriculture Organization of the United Nations, Rome, $97 \mathrm{p}$.

[7] Gee, G.W. and Or, D. (2002) Particle Size Analysis. In: Dane, J.H. and Topp, D.C., Eds., Methods of Soil Analysis, Part 4. Physical Methods, ASA and SSSA, Madison, WI, 255-293. 
[8] Grossman, R.P. and Reinschi, T.G. (2002) Bulk Density and Linear Extensibility. In: Dane, J.H. and Topp, D.C., Eds., Methods of Soil Analysis, Part 4. Physical Methods, ASA and SSSA, Madison, WI, 201-228. https://doi.org/10.2136/sssabookser5.4.c9

[9] Foth, H.D. (1984) Fundamentals of Soil Science. 7th Edition, John Wiley and Sons, New York, 435 p.

[10] Hendershot, W.H., Laland, H. and Duquette, M, (1993) Soil Reaction and Exchangeable Acidity. In: Carter, M.R., Ed., Soil Sampling and Methods of Soil Analysis, Canadian Society of Soil Science, Lewis Publishers, London, 141-145.

[11] Soil Survey Staff (2010) Keys to Soil Taxonomy. 11th Edition, USDA-NRCS, Washington DC, $338 \mathrm{p}$.

[12] Soil Survey Staff (2003) Keys to Soil Taxonomy. 9th Edition, Natural Resources Conservation Service, United States Department of Agriculture (USDA), Washington DC, $332 \mathrm{p}$.

[13] Bremner, J.M. (1996) Nitrogen Total. In: Sparus, D.L., Ed., Methods of Soil Analysis Part 3, Chemical Methods, Volume 5, Soil Science Society of America Book Series, Madison, WI, 1085-1122.

[14] Olson, R.S. and Sommers, L.E. (1982) Phosphorous. In: Page, A.L., Miller, R.H. and Keeney, D.R., Eds., Methods of Soil Analysis, American Society of Agronomy, Madison, WI, 403-430.

[15] Wilding, L.P., Bouma, J. and Boss, D.W. (1994) Impact of Spatial Variability on Interpretative Modeling. In: Bryant, R.B. and Arnold, R.W., Eds., Quantitative Modeling of Soil Forming Process, Volume 39, SSSA Special Publication, Madison, WI, 61-75.

[16] Esu, I.E (1991) Detailed Soil Survey of NIHORT Farm at Bunkure, Kano State, Nigeria. Institute for Agricultural Research, Ahmadu Bello University, Zaria.

[17] Iqbal, J., Thomasson, J.A., Jenkins, J.N., Owens, P.R. and Whisler, F.D. (2005) Spatial Variability Analysis of Soil Physical Properties of Alluvial Soils. Soil Science Society of America Journal, 69, 1338-1350. https://doi.org/10.2136/sssaj2004.0154

[18] Salako, F.K. (2003) Soil Physical Conditions in Nigeria Savannas and Biomass Production. A Lecture Given at the College on Soil Physics, Trieste.

[19] Landon, J.R. (1991) Booker Tropical Soil Manual: A Handbook for Soil Survey and Agricultural Land Evaluation in the Tropics and Sub-Tropics. Addison Wesley Longman Limited, Essex, 472 p.

[20] Ukaegbu, E.P. and Akamigbo, F.O.R. (2004) Influence of Physiography on the Properties and Land Use of Soils of the Cross River Plains: A Case Study of a Strip of Land at Ishiagu, Ebonyi State. In: Proceedings of the 29th Annual Conference of the Soil Science Society of Nigeria, University of Agriculture, Abeokuta, 103-109.

[21] Eshett, E.T., Omoeti, J.A.I. and Juo, A.S.R. (1990) Physico-Chemical Morphological and Clay Mineralogical Properties of Soils Overlying Basement Complex Rocks in Ogoja, Northern Cross River State of Nigeria. Soil Science and Plant Nutrition, 36, 203-214. https://doi.org/10.1080/00380768.1990.10414985

[22] Onweremadu, E.U. (2007) Pedology of Near Gully Sites and Its Implications on the Erodibility of Soils of Central Southeastern Nigeria. Research Journal of Environmental Sciences, 1, 71-76. https://doi.org/10.3923/rjes.2007.71.76

[23] Enplan Group (1981) Oramiriukwa River Project Report. Anambra-Imo River Basin Development Authority, Owerri. 
[24] Njoku, B.O. and Ogbuehi, S.N. (1982) Soil Fertility Aspects of Mealy Bug and Green Spider Control. In: Proceedings of the International Workshop on Control of Cassava Meal Bugs and Green Spider Mites, March 1982, 7-11.

[25] Duguma, B., Kang, B.Y. and Okali, D.U.U. (1988) Effects of Liming and Phosphorus Application on Performance of Leucaene leucocephala in Acid Soils. Plant and Soil, 110, 57-61. https://doi.org/10.1007/BF02143539

[26] Osuji, G.E., Eshett, E.T., Oti. N.N. and Ibeawuchi, I.I. (2002) Land Use Practice and the Predisposition of Selected Watersheds in Imo State to Erosion. In: Proceedings of the 36 th Annual Conference of the Agricultural Society of Nigeria, Federal University of Technology, Owerr, Nigeria, 397-401.

[27] Ogbodo, E.N. (2013) The Fertility and Management Imperatives of the Degraded Upland Soils of Ebonyi State, Southeast, Nigeria. Nigerian Journal of Soil Science, 23, 168-177.

[28] Onweremadu, E.U. (2012) Optimum Soil Nutrients: A Sine Qua Non for Sustainable Agriculture for Food and Nutrition Security. In: Miransari, M., Ed., Soil Nutrients, Nova Science Publishers Inc., New York, 215-265. 


\section{Appendix}

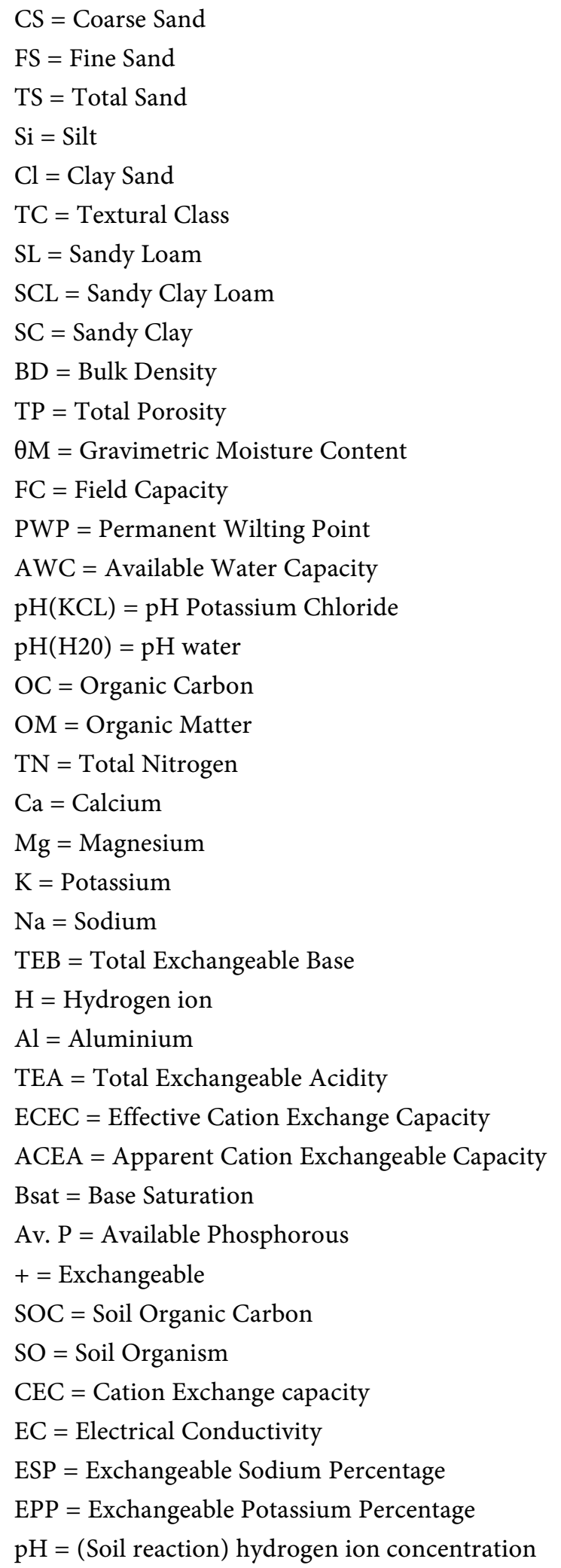

